\author{
NATALIA WALTER \\ Uniwersytet im. Adama Mickiewicza \\ w Poznaniu
}

\title{
PEDAGOGIKA 2.0. O POTRZEBIE KSZTAŁCENIA SPECJALISTÓW Z ZAKRESU E-LEARNINGU
}

\begin{abstract}
Walter Natalia, Pedagogika 2.0. O potrzebie kształcenia specjalistów z zakresu e-learningu [Education 2.0. On the need for educating e-learning professionals]. „Neodidagmata” 35, Poznań 2013, Adam Mickiewicz University Press, pp. 145-150. ISBN 978-83-232-2685-7. ISSN 0077-653X.

One can now observe a rapid development of higher education that is aimed at the extensive use of the Internet in teaching. This creates a need for educating students who would be able to define and organize online teaching activities. Apart from the frequently mentioned computer-related skills, students should also demonstrate competencies in education (including didactics) and the psychology of learning. Also, a thorough knowledge of online teaching methods and of how to adapt them to the teaching content, goals, effects as well as methods of grading and evaluation produces a new profession which is much needed in the job market. In the paper we justify in detail the need for educating specialists in e-learning based on state-of-the-art educational standards and present recent observations and analyses.
\end{abstract}

Natalia Walter, Uniwersytet im. Adama Mickiewicza w Poznaniu, Wydziat Studiów Edukacyjnych, Zakład Technologii Ksztatcenia, ul. Stowackiego 20, 60-823 Poznań, Polska - Poland.

Obserwowany rozwój uczelni wyższych w kierunku wykorzystania Internetu w edukacji tworzy jednocześnie potrzebę kształcenia osób mogących w sposób kompleksowy organizować nauczanie on-line. Oprócz często wskazywanych kompetencji informatycznych, tacy specjaliści powinni charakteryzować się kompetencjami z zakresu pedagogiki (w tym dydaktyki) oraz psychologii uczenia się. Jednoczesna dogłębna znajomość metod kształcenia on-line oraz wiedza na temat dostosowania ich do treści, celów, efektów, sposobów oceniania, a także ewaluacji tworzy nową jakość, która jest coraz bardziej pożądana na rynku pracy. W artykule szczegółowo uzasadniono potrzebę kształcenia specjalistów z zakresu e-learningu, którą 
oparto na aktualnym stanie wiedzy pedagogicznej oraz bieżących obserwacjach i analizach.

Zmiany w szkolnictwie wyższym, związane z jednej strony z integracją europejską, procesem bolońskim i wprowadzeniem Krajowych Ram Kwalifikacyjnych, z drugiej natomiast z koncepcją uczenia ustawicznego (LLL), kształtowaniem kluczowych kompetencji propagowanych przez Unię Europejską, dotyczą między innymi kompleksowej zmiany w zakresie pojmowania edukacji stacjonarnej, jak i nowych (czy w nowy sposób postrzeganych) metod kształcenia. Zmiany, o których mowa obejmują uczenie kompleksowe, elastyczne i dualne ${ }^{1}$.

Uczenie kompleksowe dotyczy nowych rodzajów umiejętności, tak zwanych umiejętności XXI w., niezbędnych w społeczeństwie jutra. Kluczową koncepcją w uczeniu jest kompleksowe łączenie wiedzy, umiejętności i postaw oraz swobodne i elastyczne przenikanie się ich, a także nabywanie nowych, niezbędnych na różnych etapach edukacji czy potem pracy zawodowej. Metody nauczania, obecnie stosowane w celu rozwijania wszystkich tych elementów i płynnego ich przenikania, to metody oparte na: nauczaniu problemowym, analizie przypadków i sytuacji (case study, situation study), metodzie projektów czy nauczaniu zorientowanym na kształcenie kompetencji. Kładzie się nacisk na prezentowanie wiedzy, ale też na aspekty praktyczne oraz testowanie ${ }^{2}$.

Jeśli chodzi o uczenie elastyczne, zwraca się uwagę z jednej strony na niestacjonarne formy nauczania (niezależność od czasu i miejsca), z drugiej na indywidualizację procesu kształcenia i nauczanie zorientowane na studenta (dostosowane do jego potrzeb, możliwości i oczekiwań) ${ }^{3}$. Studenci poszukują takich możliwości edukacyjnych, które będą korelowały z ich równoczesną pracą, zarówno rozpatrując aspekt czasowo-przestrzenny, jak i dostosowanie do potrzeb rynku pracy, a nawet konkretnego stanowiska. Edukacja kompleksowa i elastyczna spotykają się w obszarze tak zwanej koncepcji dualnej, łączącej edukację akademicką z nabywaniem praktycznych umiejętności profesjonalnych, czyli płynnym przechodzeniem od studiów do miejsca pracy ${ }^{4}$.

Wszystkie trzy koncepcje funkcjonują przy intensywnym wykorzystaniu technologii informacyjno-komunikacyjnych, a e-learning wspiera ich stosowanie. Taki zintegrowany e-learning umożliwia zarówno elastyczność

${ }^{1}$ W. Jochems, J. Merriënboer, R. Koper, An introduction to integrated e-learning, [w:] W. Jochems, J.J.G. Van Merriënboer, R. Koper (red.), Integrated E-learning: Implications for Pedagogy, Technology and Organization, RoutledgeFalmer, London 2004, s. 3.

2 Tamże, s. 3.

3 Tamże, s. 4.

4 Tamże, s. 5. 
edukacyjną, kompleksowość oraz dualizm naukowo-praktyczny. E-learning nie może być traktowany jako niezależna strategia edukacyjna. Jest on raczej formą, ściśle związaną z kształceniem na określonym etapie. E-learning to zatem nie uczenie elektroniczne, a raczej integralna część procesu nauczania-uczenia się wykorzystująca technologie informacyjno-komunikacyjne, wspierająca organizowanie tego procesu i uelastycznianie go. W e-learningu wykorzystuje się tradycyjne metody nauczania i dostosowuje je do możliwości technologicznych oraz, co ważne, dydaktycznych. E-learning łączy w sobie doświadczenia informatyków, administracji szkolnictwa oraz pedagogiki.

\section{E-LEARNING W SZKOLE WYŻSZEJ}

W literaturze ostatnio sporo miejsca poświęca się zagadnieniu dydaktyki kształcenia zdalnego czy dydaktyki e-learningu. Pojawiają się pozycje, na przykład Kształcenie na odległość. Podstawy dydaktyki autorstwa J. Bednarka i E. Lubiny ${ }^{5}$, w których kompleksowo podchodzi sie do tego szczególnego zagadnienia, nie ograniczając się wyłącznie do przedstawienia metod oraz dostosowanych do nich sposobów weryfikacji wiedzy uczniów. Wśród wielu uczelni wyższych wykorzystujących e-learning pojawia się problem właśnie nie tylko z techniczną stroną jego wdrażania, co raczej z pedagogiką. Jeżeli bowiem traktujemy e-learning nie jako uczenie elektroniczne, ale właśnie jako integralną część procesu nauczania-uczenia się, musi on być profesjonalnie przygotowany, z wykorzystaniem wiedzy z zakresu psychologii uczenia się, psychologii społecznej, rozwojowej, a nade wszystko poznawczej, z punktu widzenia różnych koncepcji psychologicznych człowieka, a także dydaktyki. Istotne jest rozumienie procesu komunikowania społecznego w formie zdalnej, funkcjonowania mediów, a w szczególności Internetu.

Analizując sylwetkę specjalisty $\mathrm{w}$ zakresie e-learningu, postanowiono skonstruować taki program studiów, który będzie obejmował wiedzę ze wszystkich wymienionych powyżej obszarów i dziedzin. Najbardziej spójny w tym zakresie był program kierunku pedagogika na Uniwersytecie im. Adama Mickiewicza w Poznaniu. Na studiach I stopnia obejmował on bowiem zarówno podstawy psychologii, socjologii, filozofii, jak i dydaktyki ogólnej czy teorii wychowania. Postanowiono stworzyć specjalność, która dodatkowo wyposaży studenta $\mathrm{w}$ umiejętności i wiedzę z zakresu techno-

5 J. Bednarek, E. Lubina, Kształcenie na odległość. Podstawy dydaktyki, Wyd. Nauk. PWN, Warszawa 2008. 
logii informacyjnych oraz pedagogiczno-psychologicznych uwarunkowań nowych mediów, w tym edukację medialną. Tak powstała specjalność kształcenie zdalne, która funkcjonuje od roku akademickiego 2010/2011.

\section{INDYWIDUALIZACJA W KSZTAŁCENIU ZDALNYM}

E-learning tak bardzo utożsamiany bywa $\mathrm{z}$ technologiami informacyjno-komunikacyjnymi, że często zapomina się o tym, iż jest to integralna część kształcenia, którego treścią jest uczeń, nauczyciel, przedmiot kształcenia oraz środowisko dydaktyczno-wychowawcze ${ }^{6}$. Proces nauczania-uczenia się uwarunkowany jest wieloma kwestiami, ale wśród kluczowych wyłaniają się koncepcje psychologiczne człowieka. Sposób patrzenia na ucznia, podejście do zmian $\mathrm{w}$ jego osobowości wpływają na tworzenie przestrzeni e-learningu, organizowanie całego procesu kształcenia. Najczęściej wymienia się tu behawioryzm, koncepcję psychodynamiczną, poznawczą (wraz z konstruktywizmem, jeśli chodzi o struktury poznawcze oraz koneksjonizmem i neurobiologią w kontekście przetwarzania informacji), a także humanistyczną7. Znajomość tych koncepcji jest niezbędna zarówno w momencie tworzenia programów kształcenia, jak i w projektowaniu kursów zdalnych. E-learning bardzo silnie uwzględniać może indywidualne preferencje uczniów, ponieważ jest, jak wspomniano, elastyczny. By tak się stało, konieczna jest pełna wiedza na temat koncepcji psychologicznych człowieka, psychologii rozwoju, psychologii osobowości, psychologii społecznej i poznawczej.

Kolejną kwestią jest dostosowanie starannie dobranych metod kształcenia zarówno do indywidualnych potrzeb ucznia, jak i do realizacji założonych celów oraz efektów, a także do możliwości technicznych, jakie łączą się z e-learningiem (platformami, technologiami Web 2.0 czy 3.0). Dydaktyka ogólna oraz dydaktyka kształcenia zdalnego obejmują wiedzę i umiejętności z zakresu formułowania celów i treści kształcenia, uwzględniania zasad kształcenia, form i metod, a także kontroli i oceny. Kurs e-learningowy nie może być zbiorem przypadkowo umieszczonych materiałów tekstowych, wizualnych, audialnych, audiowizualnych czy multimedialnych. Każda treść pojawiająca się na platformie musi być dobrana adekwatnie do konkretnych uczestników, do ich możliwości, zainteresowań oraz potrzeb. Ponadto, treści muszą być przekazane właściwymi metodami, odpowiadającymi celom i efektom kształcenia.

${ }^{6}$ W. Okoń, Wprowadzenie do dydaktyki ogólnej, Wyd. Akad. Żak, Warszawa 2003, s. 133.

7 J. Kozielecki, Koncepcje psychologiczne człowieka, Wyd. Akad. Żak, Warszawa 2000. 
Większość tradycyjnych metod ma swoje odpowiedniki w nauczaniu on-line. Wykorzystując potencjał Web 2.0, coraz częściej stosuje się, oprócz metod asymilacji wiedzy, wspomniane na początku metody samodzielnego dochodzenia do wiedzy (metodę problemową, przypadków, sytuacyjną) oraz metody praktyczne (np. WebQuest). Ponadto, projektując kurs zdalny, należy uwzględniać różne rodzaje organizacji pracy uczestników - zarówno pracę indywidualną, jak i zbiorową czy grupową, co z kolei związane jest z kształceniem kompetencji społecznych. Dlatego założono, że specjalista $\mathrm{w}$ dziedzinie kształcenia zdalnego będzie miał wiedzę pedagogiczną w zakresie samego procesu nauczania-uczenia się, ale także konstruowania metod kształcenia zdalnego oraz ewaluacji istniejących narzędzi i aplikacji służących wspieraniu edukacji zdalnej. Będzie też potrafił w sposób kompetentny zarządzać szkoleniami on-line, pełnić nad nimi nadzór dydaktyczny oraz technologiczny.

\section{KOMPETENCJE CYFROWE}

Specjalista do spraw e-learningu musi oczywiście charakteryzować się kompetencjami cyfrowymi. W dokumencie opracowanym przez grupę ekspertów, w ramach projektu Unii Europejskiej Key Competences For Lifelong Learning. A European Reference Framework ${ }^{8}$, scharakteryzowano kompetencje kluczowe dla edukacji, czyli takie, które są niezbędne każdemu człowiekowi w rozwoju osobistym, w aktywnym uczestnictwie w życiu społecznym oraz $\mathrm{w}$ pracy zawodowej. Wymieniono: znajomość języka ojczystego, znajomość języków obcych, kompetencje matematyczne oraz podstawowe kompetencje dotyczące nauki i technologii, kompetencje cyfrowe, „uczenie się, jak się uczyć", kompetencje społeczne i personalne, inicjatywność i przedsiębiorczość, świadomość i ekspresję kulturową. Kompetencje cyfrowe są niezbędne między innymi w tworzeniu kursów zdalnych, a obejmują umiejętności związane $\mathrm{z}$ tworzeniem szeroko rozumianych komunikatów medialnych (tekstowych, wizualnych, audiowizualnych, multimedialnych), komunikowaniem zdalnym, projektowaniem stron WWW, kursów, posługiwaniem się usługami Web 2.0 i wirtualnymi środowiskami edukacji oraz platformami e-learningowymi. Specjalista do spraw kształcenia zdalnego musi sprawnie posługiwać się narzędziami do tworzenia kompleksowych szkoleń on-line, w tym także zarządzać dowolną platformą e-learningową. Nie są to jednak kompetencje stricte informatyczne, a raczej związane

8 The Key Competences for Lifelong Learning - A European Framework, Luxembourg, 2007, $<$ http://ec.europa.eu/dgs/education_culture/publ/pdf/ll-learning/keycomp_en.pdf>, [dostęp: 8.05.2013]. 
z wiedzą i umiejętnościami w zakresie nowych technologii informacyjnych na gruncie edukacyjnym.

\section{PODSUMOWANIE}

W wydanej w roku 2013 książce Zwrot cyfrowy w humanistyce ${ }^{9}$ starannie opisano zmiany, jakie zachodzą w metodologii badań humanistycznych i społecznych. Warto zauważyć, iż ten "zwrot cyfrowy” dotyczy też pedagogiki, a zwłaszcza kwestii metodycznych. Uczenie się w społeczeństwie wiedzy, w społeczeństwie informacyjnym wygląda znacząco inaczej niż w czasach, gdy rzeczywistość cyfrowa nie była tak dominująca. Internet stał się przestrzenią edukacyjną, która daje ogromne możliwości nauczycielom i uczniom. Odpowiednie zagospodarowanie tej przestrzeni wymaga wiedzy i umiejętności w zakresie "pedagogiki 2.0" oraz technologii informacyjno-komunikacyjnych.

\section{LITERATURA}

Bednarek J., Lubina E., Ksztatcenie na odległość. Podstawy dydaktyki, Wyd. Nauk. PWN, Warszawa 2008.

Jochems W., Merriënboer J., Koper R., An introduction to integrated e-learning, [w:] W. Jochems, J.J.G. Van Merriënboer, R. Koper (red.), Integrated E-learning: Implications for Pedagogy, Technology and Organization, RoutledgeFalmer, London 2004.

Kozielecki J., Koncepcje psychologiczne człowieka, Wyd. Akad. Żak, Warszawa 2000.

Okoń W., Wprowadzenie do dydaktyki ogólnej, Wyd. Akad. Żak, Warszawa 2003.

Radomski A., Bomba R. (red.), Zwrot cyfrowy w humanistyce. Internet/Nowe media/Kultura 2.0, E-naukowiec, Lublin 2013.

\section{NETOGRAFIA}

The Key Competences for Lifelong Learning - A European Framework, Luxembourg 2007, $<$ http:/ /ec.europa.eu/dgs/education_culture/publ/pdf/ll-learning/keycomp_en. pdf>, [dostęp: 8.05.2013].

${ }_{9}$ A. Radomski, R. Bomba (red.), Zwrot cyfrowy w humanistyce. Internet/Nowe media/Kultura 2.0, E-naukowiec, Lublin 2013. 